\title{
In vitro evaluation of visible light-activated titanium dioxide photocatalysis for in-office dental bleaching
}

\author{
Marla CUPPINI ${ }^{1}$, Vicente Castelo Branco LEITUNE'1, Marcela de SOUZA ${ }^{1}$, Annelise Kopp ALVES ${ }^{2}$, \\ Susana Maria Werner SAMUEL ${ }^{1}$ and Fabrício Mezzomo COLLARES ${ }^{1}$ \\ ${ }^{1}$ Department of Conservative Dentistry, Dental Materials Laboratory, School of Dentistry, Universidade Federal do Rio Grande do Sul, Rua Ramiro \\ Barcelos 2492, Porto Alegre, Rio Grande do Sul 90035-003, Brazil \\ ${ }^{2}$ Department of Materials, Ceramic Materials Laboratory, School of Engineering, Universidade Federal do Rio Grande do Sul, Porto Alegre, Rio \\ Grande do Sul 90035-003, Brazil \\ Corresponding author, Fabrício Mezzomo COLLARES; E-mail: fabricio.collares@ufrgs.br
}

\begin{abstract}
The evaluation of the photocatalysis of visible light activated titanium dioxide employed in hydrogen peroxide $\left(\mathrm{H}_{2} \mathrm{O}_{2}\right)$ was carried using seven $\mathrm{H}_{2} \mathrm{O}_{2}$ solutions (3.5 and 35\%) and/or methylene blue (MB), with or without light irradiation (LI); the absorbance of MB was the bleaching indicator. Color analysis was performed on bovine teeth $(n=12)$ using two different concentrations of $\mathrm{H}_{2} \mathrm{O}_{2}, 6$ and $35 \%$ associated with titanium dioxide $\left(\mathrm{TiO}_{2}\right)$. Data were analyzed with one and two-way ANOVA, and significance level of $p<0.05$. Solutions containing $\mathrm{MB}, \mathrm{H}_{2} \mathrm{O}_{2}$ at 3.5 or $35 \%$, and $\mathrm{TiO}_{2}$, followed by $\mathrm{LI}$, showed significant difference when compared with other groups. Greater MB reduction was found in 35\% concentration. $\mathrm{H}_{2} \mathrm{O}_{2} 35 \%+\mathrm{TiO}_{2}$ gel showed no difference in comparison to control group. All groups for the color analysis assay showed $\Delta E$ higher than 3.3. In conclusion, $\mathrm{TiO}_{2}$ and $\mathrm{H}_{2} \mathrm{O}_{2}$ association is a promisor alternative for reducing the clinical time of in-office dental bleaching.
\end{abstract}

Keywords: Tooth bleaching, Hydrogen peroxide, Titanium dioxide

\section{INTRODUCTION}

Tooth bleaching is considered one of the most important dentistry treatments for patient satisfaction ${ }^{1)}$. Patient's demand for both healthy and esthetically appearance has rapidly grown in recent years ${ }^{2}$. The esthetics of whiter teeth cause direct impact on smiling ${ }^{3)}$, laughing and also have been linked to social competence, intellectual ability, successful interpersonal relationships and even to psychological stability ${ }^{1,2)}$. Gathering this information, esthetic dentistry has focused its attention on bleaching, and a series of techniques and materials are constantly developed for this purpose.

The success of in-office tooth whitening relies mainly on hydrogen peroxide $\left(\mathrm{H}_{2} \mathrm{O}_{2}\right)$ concentration and application period ${ }^{4,5)}$. The home bleaching typically contains lower concentration of $\mathrm{H}_{2} \mathrm{O}_{2}$ and greater contact time when compared to in-office bleaching products, which generally contains higher concentrations of $\mathrm{H}_{2} \mathrm{O}_{2}$ $(20-38 \%)$ with shorter gel-contact periods ${ }^{4,5}$. Another gel utilized for home bleaching is the carbamide peroxide, a systematic review comparing the $\mathrm{H}_{2} \mathrm{O}_{2}$ and carbamide peroxide showed the color change in shade guide units (SGU) and $\Delta E$, the tray-delivered carbamide peroxide gels have a slightly better whitening efficacy than $\mathrm{H}_{2} \mathrm{O}_{2}$ based products in terms of $\Delta E$, although, the result should be interpreted with caution as the data of $\triangle S G U$ did not show statistical difference between the products ${ }^{6}$. Inoffice bleaching has advantages in terms of professional control, avoidance of material ingestion, possibility of

Color figures can be viewed in the online issue, which is available at J-STAGE.

Received Jun 20, 2017: Accepted Apr 1, 2018

doi:10.4012/dmj.2017-199 JOI JST.JSTAGE/dmj/2017-199 faster results and treatment time reduction ${ }^{7}$.

Different light sources have been used in association with in-office bleaching agents, to accelerate the chemical reaction rates of the tooth bleaching process. The literature reports activation of bleaching agents by light using halogen, light emitting diode (LED) or laser ${ }^{8,9}$. Light activated bleaching procedures leads to an increase in hydroxyl radicals release through the rise in temperature ${ }^{9)}$. However, the increase in heat may cause irreversible damage to pulpal tissues ${ }^{9,10)}$. The effectiveness of light sources for in-office bleaching has been controversial, and its contribution to commonly used bleaching procedures remains unknown ${ }^{11-13)}$.

Apart from the effect of light sources on accelerating the chemical reaction of bleaching gels, some researches have been made into catalyzing molecules such as titanium dioxide $\left(\mathrm{TiO}_{2}\right)$, which it is known to be an important photocatalyst semiconductor in a wide range of environmental applications ${ }^{14)}$. In order to provide faster results on bleaching, $\mathrm{TiO}_{2}$ is a great photocatalyst agent option due to its oxidizing properties, absence of toxicity, photo and chemical stability in a wide $\mathrm{pH}$ band ${ }^{14-16)}$. The energy of its band gap is $+3.2 \mathrm{eV}$ for anatase phase, and therefore, absorbs ultraviolet light (388 $\mathrm{nm}$ wavelength), producing oxygen and hydroxyl radicals ${ }^{17}$. Nevertheless, $\mathrm{TiO}_{2}$ has also shown to react at visible light exposure of $400 \mathrm{~nm}$ vicinity, which is the same wavelength of common light sources used in dental light curing units ${ }^{18)}$, probably due to the rutile polymorph phase. One of the most studied $\mathrm{TiO}_{2}$ for catalysis use is known as AEROXIDE ${ }^{\circledR} \mathrm{TiO}_{2} \mathrm{P} 25$ (Evonik Industries, Essen, Germany), and it consists in a highly dispersed 
powder composed by a mixture of $80 \%$ of anatase and $20 \%$ of rutile, with a surface area of $50 \mathrm{~m}^{2} \mathrm{~g}^{-1}$ and an average particle size of $21 \mathrm{~nm}$.

In this way, low concentrations of $\mathrm{H}_{2} \mathrm{O}_{2}$ gels containing $\mathrm{TiO}_{2}$ have recently been introduced for inoffice tooth bleaching, yet, the bleaching protocol for different $\mathrm{H}_{2} \mathrm{O}_{2}$ concentrations and $\mathrm{TiO}_{2}$ proportion are not well defined ${ }^{18,19)}$. The challenge is to achieve effectiveness with lower concentrations of $\mathrm{H}_{2} \mathrm{O}_{2}$, reducing the adverse effects, such as dentin and gingival sensitivity, and chair time. Based on this background, the objective of this study was to evaluate the photocatalyst effects of visible light activated (VLA) $\mathrm{TiO}_{2}$ and if the addition of $\mathrm{TiO}_{2}$ in low and high $\mathrm{H}_{2} \mathrm{O}_{2}$ concentrations gels can reduce the contact time application. The null hypothesis is that the addition of $\mathrm{TiO}_{2}$ would not accelerate the bleaching process among different concentrations of $\mathrm{H}_{2} \mathrm{O}_{2}$ gel.

\section{MATERIALS AND METHODS}

\section{Photocatalytic analysis}

Seven experimental solutions were prepared by mixing $\mathrm{H}_{2} \mathrm{O}_{2}$ with/without $10 \mathrm{mg}$ of $\mathrm{TiO}_{2}$ AEROXIDE ${ }^{\circledR}$ P25 (Evonik Industries) with an aqueous solution of methylene blue dye 20 ppm (Sigma Aldrich Chemical, St. Louis, MO, USA), according to Table 1. The bleaching gel utilized was $\mathrm{H}_{2} \mathrm{O}_{2}$-based in two different concentrations: 35 and $3.5 \%$ (Whiteness HP, FGM, Joinville, Brazil). Other components of the gel are neutralizing agents, glycol and deionized water. For each group, the solutions were developed separately, and a volume of $4 \mathrm{~mL}$ was poured into a quartz cell recipient. The mix ratio for the methylene blue was $4 \mathrm{mg} / 4 \mathrm{~mL}$ and for the bleaching gel, to each $4.96 \mathrm{~g}$ it was added $10 \mathrm{mg}$ of $\mathrm{TiO}_{2}$ in experimental groups.

The visible light-curing unit employed in this study was Radii Cal-LED unit, $1,200 \mathrm{~mW} / \mathrm{cm}^{2}, 440-480 \mathrm{~nm}$ wavelength (Radii Cal, SDI, Bayswater, Australia). An aluminum foil wrapped each quartz cell and the solutions were light irradiated (LI) with continuous irradiance for $5 \mathrm{~min}$ on the top of each quartz cell. During light irradiation, the solution was stirred using a magnetic stirrer (Jintan Medical Instrument Factory, Jiangsu, China). After light activation, the aluminum foil was removed, and the quartz cell was left undisturbed for 10 min, totaling $15 \mathrm{~min}$ of action. This process was repeated three times $(n=3)$. The LED unit intensity was verified prior each utilization (ECEL Radiometer, Ribeirão Preto, Brazil).

For the absorbance analysis, $\mathrm{TiO}_{2}$ was removed using a filter $(0.21 \mu \mathrm{m})$ coupled with a syringe and the solutions were placed into another cell. The absorbance at $660 \mathrm{~nm}$ was measured using a spectrophotometer (Agilent, Santa Clara, CA, USA) to determine MB concentration, as an indicator of the bleaching effect. In the experimental solutions, the remaining $\mathrm{MB}$ concentrations were determined by the absorbance of the experimental solution $(A s)$ compared with a pure MB solution $(A c)$, according to the following equation:

$$
C=\frac{A s}{A c} \times 100
$$

$C=$ Concentration of MB after irradiation

$A s=$ absorbance of experimental solution after irradiation.

$A c=$ absorbance of pure solution MB $20 \mathrm{ppm}$ (control group) before irradiation.

After the tests using MB organic dye, this study evaluated the behavior of $\mathrm{TiO}_{2}$ when added to bleaching products currently marketed.

\section{Teeth color change analysis}

Thirty-six extracted bovine incisors were used in this study. The crowns were separated from the roots using a diamond disc and cleaned by removing the remnant soft tissue with a scalpel. Pulpal tissue was also removed. A stain solution was prepared by coffee immersion (100 g, Mellita, Avaré, Brazil) in $1 \mathrm{~L}$ of boiling water. After cooling, specimens were immersed into the solution and stored in a refrigerator for 7 days at $4^{\circ} \mathrm{C}$. After removing from the solution, the specimens were rinsed, dried, and stored in distilled water at $4^{\circ} \mathrm{C}$. Labial surfaces were covered with a masking tape containing a $6 \mathrm{~mm}$-diameter fitting the spectrophotometer's scanner (CM2600 Konica Minolta, Osaka, Japan). This procedure ensured measuring the same area at each step.

The specimens were randomly assigned into three groups $(n=12)$ and the bleaching gel was applied at the experimental surface using a disposable brush. After

Table 1 Formulations of the experimental solutions (sol) for $\mathrm{H}_{2} \mathrm{O}_{2}$ at $35 \%$ and $3.5 \%$

\begin{tabular}{lcccc}
\hline \multicolumn{1}{c}{ Solution } & $\mathrm{MB}$ & $\mathrm{H}_{2} \mathrm{O}_{2}$ & $\mathrm{TiO}_{2}$ & Light Activation \\
\hline SolMB & $\mathrm{X}$ & - & - & - \\
SolMB $+\mathrm{H}_{2} \mathrm{O}_{2}$ & $\mathrm{X}$ & $\mathrm{X}$ & - & - \\
SolMB $+\mathrm{H}_{2} \mathrm{O}_{2}+\mathrm{LA}$ & $\mathrm{X}$ & $\mathrm{X}$ & - & $\mathrm{X}$ \\
SolMB$+\mathrm{TiO}_{2}$ & $\mathrm{X}$ & - & $\mathrm{X}$ & - \\
SolMB$+\mathrm{TiO}_{2}+\mathrm{LA}$ & $\mathrm{X}$ & - & $\mathrm{X}$ & $\mathrm{X}$ \\
$\mathrm{SolMB}^{\mathrm{H}} \mathrm{H}_{2} \mathrm{O}_{2}+\mathrm{TiO}_{2}$ & $\mathrm{X}$ & $\mathrm{X}$ & $\mathrm{X}$ & - \\
$\mathrm{SolMB}_{\mathrm{H}_{2} \mathrm{O}_{2}+\mathrm{TiO}_{2}+\mathrm{LA}}$ & $\mathrm{X}$ & $\mathrm{X}$ & $\mathrm{X}$ & $\mathrm{X}$ \\
\hline
\end{tabular}


treatment time, the bleaching gel was removed using damp gauze. The specimens were washed thoroughly under tap water and gently dried. The three groups were: Group $\mathrm{H}_{2} \mathrm{O}_{2}$ 35\%: office-bleaching agent $\mathrm{H}_{2} \mathrm{O}_{2}$ at $35 \%$ without $\mathrm{TiO}_{2}$ addition (control). Each tooth was light activated with continuous irradiance for $5 \mathrm{~min}$ and the bleaching agent was left on the specimens for further $40 \mathrm{~min}$, totaling $45 \mathrm{~min}$ of gel action, according to the manufacturer's instructions. Group $\mathrm{H}_{2} \mathrm{O}_{2} \quad 35 \%+\mathrm{TiO}_{2}$ : office-bleaching agent $\mathrm{H}_{2} \mathrm{O}_{2}$ at $35 \%$ with the addition of $10 \mathrm{mg}$ of $\mathrm{TiO}_{2}$. Each tooth was light activated with continuous irradiance for $5 \mathrm{~min}$ and the bleaching agent was left on the specimens for a further $10 \mathrm{~min}$, totaling $15 \mathrm{~min}$ of gel action. Group $\mathrm{H}_{2} \mathrm{O}_{2} \quad 6 \%+\mathrm{TiO}_{2}$ : homebleaching agent $\mathrm{H}_{2} \mathrm{O}_{2}$-based at $6 \%$, potassium nitrate and sodium fluoride are desensitizers of the gel (White Class, FGM) with the addition of $10 \mathrm{mg}$ of $\mathrm{TiO}_{2}$. Each tooth was light activated with continuous irradiance for 5 min and the bleaching agent was left on the specimens for a further $10 \mathrm{~min}$, totaling $15 \mathrm{~min}$ of gel action. The final concentration of the bleaching gel was $0.2 \%$, since to each $4.96 \mathrm{~g}$ it was added $10 \mathrm{mg}$ of $\mathrm{TiO}_{2}$ in experimental groups.

As baseline data, the teeth surfaces were recorded prior to bleaching ( $\mathrm{L}_{\text {initial }}, \mathrm{a}_{\text {initial }}$ and $\left.\mathrm{b}_{\text {initial }}\right)$. Bleaching treatments and measurements were subsequently repeated 3 times on the specimens, with one-week intervals, which the samples were stored in distilled water. Each color measurement was carried out $24 \mathrm{~h}$ after the bleaching treatment $\left(\mathrm{L}_{\text {final }}, \mathrm{a}_{\text {final }}\right.$ and $\left.\mathrm{b}_{\text {final }}\right)$. The color evaluation was obtained from labial surfaces using a spectrophotometer.

The CIE $L^{*} a^{*} b^{*}$ values were assessed using the CIELAB (Commission Internationale L'Eclairage) color coordinate system, where $L^{*}$ defines lightness, $a^{*}$ denotes the red/green axis, and $b^{*}$ denotes the yellow/ blue axis. $\Delta L$ values indicate if the sample is lighter than the standard (baseline readout), with negative values indicating that the sample is darker or positive values for brighter measurements. Given $\Delta L, \Delta a$, and $\Delta b$, the total difference or distance on the CIELAB diagram can be stated as a single value, known as $\Delta E$. The color difference $(\Delta E)$ was calculated according to the following equation: $\Delta E=\left[(\Delta L)^{2}+(\Delta a)^{2}+(\Delta b)^{2}\right]^{1 / 2}$, where $\Delta E$ is the color change; $\Delta L=\mathrm{L}_{\text {final }}-\mathrm{L}_{\text {initial }} ; \Delta a=\mathrm{a}_{\text {final }}-\mathrm{a}_{\text {initial }} ; \Delta b=\mathrm{b}_{\text {final }}-\mathrm{b}_{\text {initial }}$.

\section{Statistical analysis}

For the data analysis, mean and standard deviation were calculated for each experimental solution. To evaluate the solutions containing $\mathrm{TiO}_{2}$ photocatalysis using $\mathrm{MB}$, a two-way ANOVA test was applied $\left(\mathrm{H}_{2} \mathrm{O}_{2}\right.$ concentration and $\mathrm{TiO}_{2}$ association). The color difference data $(\Delta E)$ of bovine model groups was subjected to statistical analysis with the one-way ANOVA test. Holm-Sidak test was used as a post hoc test for multiple comparisons in both analyses. The statistical analysis was performed at $5 \%$ level of significance.

\section{RESULTS}

The absorbance values for the seven experimental solutions are shown in Table 2. $\mathrm{H}_{2} \mathrm{O}_{2}$ at $35 \%$ concentration, without $\mathrm{TiO}_{2}$ and no light irradiation, showed a statistically significant difference to the same solution where light exposure was present (SolMB $+\mathrm{H}_{2} \mathrm{O}_{2}$ and SolMB $+\mathrm{H}_{2} \mathrm{O}_{2}+\mathrm{LI}$ ) resulting in great decrease when LI was present. Otherwise, the $\mathrm{H}_{2} \mathrm{O}_{2}$ at $3.5 \%$ concentration without $\mathrm{TiO}_{2}$ and nolightirradiation showed no difference compared to the same solution with light application. The solutions that comprised only MB and $\mathrm{TiO}_{2}$, showed decrease in $\mathrm{MB}$ concentration, regardless the light activation or not. When $\mathrm{H}_{2} \mathrm{O}_{2}, \mathrm{TiO}_{2}$ and light irradiation were associated (SolMB $\left.+\mathrm{H}_{2} \mathrm{O}_{2}+\mathrm{TiO}_{2}+\mathrm{LI}\right)$, the lowest values of $\mathrm{MB}$ concentration in both $\mathrm{H}_{2} \mathrm{O}_{2}$ concentrations was revealed. The association between $\mathrm{H}_{2} \mathrm{O}_{2}$ and $\mathrm{TiO}_{2}$ also showed a $\mathrm{MB}$ decrease even without light exposure (SolMB $\left.+\mathrm{H}_{2} \mathrm{O}_{2}+\mathrm{TiO}_{2}\right)$. The solutions of $\mathrm{H}_{2} \mathrm{O}_{2}$ at $35 \%$ concentration resulted in the most reduction in $\mathrm{MB}$; however $3.5 \%$ with the addition of $\mathrm{TiO}_{2}$ also decreased significantly MB concentration.

$\Delta E$ mean and standard deviation of experimental bovine teeth groups are shown in Fig. 1D. The $\mathrm{H}_{2} \mathrm{O}_{2}$

Table 2 Changes in MB concentration (ppm) at each $\mathrm{H}_{2} \mathrm{O}_{2}$ solution

\begin{tabular}{lcc}
\hline \multicolumn{1}{c}{ Solution } & $35 \%$ Mean (SD) & $3.5 \% \mathrm{Mean}(\mathrm{SD})$ \\
\hline SolMB & $100(0) \mathrm{Aa}$ & $100(0) \mathrm{Aa}$ \\
SolMB $+\mathrm{H}_{2} \mathrm{O}_{2}$ & $30.46(1.8) \mathrm{Cb}$ & $80.95(3.4) \mathrm{Ba}$ \\
SolMB+ $\mathrm{H}_{2} \mathrm{O}_{2}+\mathrm{LI}$ & $20.67(1.7) \mathrm{Db}$ & $80.07(3.8) \mathrm{Ba}$ \\
SolMB$+\mathrm{TiO}_{2}$ & $90.25(2.3) \mathrm{Ba}$ & $90.04(1.3) \mathrm{Ca}$ \\
SolMB$+\mathrm{TiO}_{2}+\mathrm{LI}$ & $90.06(1.7) \mathrm{Ba}$ & $90(2.5) \mathrm{Ca}$ \\
SolMB$+\mathrm{H}_{2} \mathrm{O}_{2}+\mathrm{TiO}_{2}$ & $9.5(1.6) \mathrm{Eb}$ & $18.5(3.8) \mathrm{Da}$ \\
SolMB$+\mathrm{H}_{2} \mathrm{O}_{2}+\mathrm{TiO}_{2}+\mathrm{LI}$ & $2(1.0) \mathrm{Fb}$ & $12.8(2.3) \mathrm{Da}$ \\
\hline
\end{tabular}

Different capital letters indicate statistical difference in the same columns.

Different small letters indicate statistical difference in the same line, $p<0.05$.

*SolMB: methylene blue solution; $\mathrm{H}_{2} \mathrm{O}_{2}$ : hydrogen peroxide; $\mathrm{TiO}_{2}$ : titanium dioxide; LI: light irradiance. 

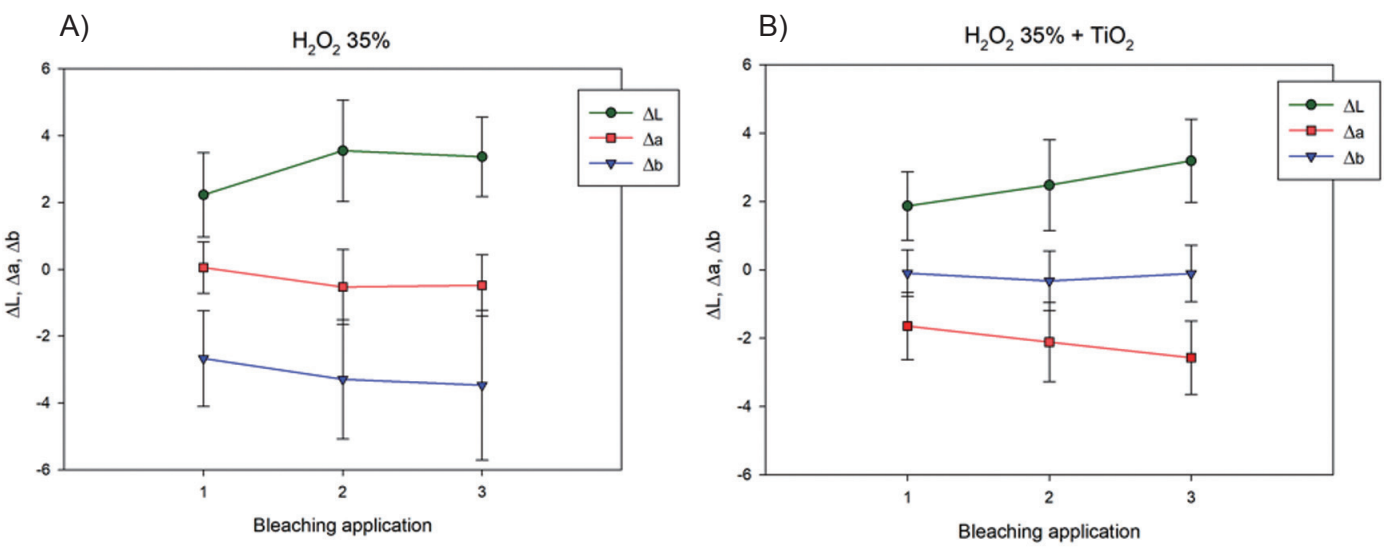

C)

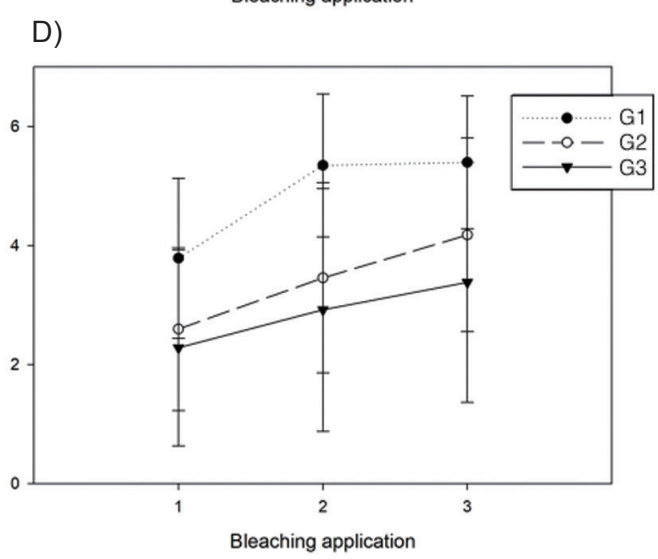

Fig. 1 A) The mean $\Delta L, \Delta a$, and $\Delta b$, values of $\mathrm{H}_{2} \mathrm{O}_{2} 35 \%$ group. B) The mean $\Delta L, \Delta a$, and $\Delta b$, values of $\mathrm{H}_{2} \mathrm{O}_{2} 35 \%+\mathrm{TiO}_{2}$. C) The mean $\Delta L, \Delta a$, and $\Delta b$, values of $\mathrm{H}_{2} \mathrm{O}_{2} 6 \%+\mathrm{TiO}_{2}$ group. D) $\Delta E$ value of each experimental group. (G1: $\mathrm{H}_{2} \mathrm{O}_{2} 35 \%$, G2: $\mathrm{H}_{2} \mathrm{O}_{2} 35 \%+\mathrm{TiO}_{2}, \mathrm{G}_{3}: \mathrm{H}_{2} \mathrm{O}_{2} 6 \%+\mathrm{TiO}_{2}$ )

$35 \%$ group, without $\mathrm{TiO}_{2}$ and with a major application time did not show statistical significant difference in comparison with $\mathrm{H}_{2} \mathrm{O}_{2} 35 \%+\mathrm{TiO}_{2}$. However, when $\mathrm{H}_{2} \mathrm{O}_{2}$ concentration was reduced $\left(\mathrm{H}_{2} \mathrm{O}_{2} 6 \%+\mathrm{TiO}_{2}\right)$, a statistically significant difference was found. The groups containing $\mathrm{TiO}_{2}$ did not show a statistically significant difference in $\Delta E$, despite the two different $\mathrm{H}_{2} \mathrm{O}_{2}$ concentrations. $\Delta L$, $\Delta a$, and $\Delta b$ values of each application in each group are shown in Fig. 1. After bleaching treatment, $\Delta L$ and $\Delta E$ values gradually increased in all groups, while $\Delta a$ and $\Delta b$ showed a progressive decrease.

Ascending order of $\Delta E$ is shown in Fig. 1D. Among the three bleaching applications, two applications of $\mathrm{H}_{2} \mathrm{O}_{2} 35 \%$ gel were enough to produce a bleaching effect. The $\mathrm{H}_{2} \mathrm{O}_{2} 6 \%+\mathrm{TiO}_{2}$ group also did not show a statistically significant difference in final bleaching effect, despite showing a lowest $\Delta E$ value. Nevertheless, a third gel application appears to be an important factor in terms of the reduction in time application for $\mathrm{H}_{2} \mathrm{O}_{2} 35 \%+\mathrm{TiO}_{2}$ group.

\section{DISCUSSION}

This in vitro study evaluated the effects of VLA $\mathrm{TiO}_{2}$ photocatalyst on bleaching using different methodologies. $\mathrm{H}_{2} \mathrm{O}_{2}$ acts as a strong oxidizing agent through the formation of free radicals, reactive oxygen molecules and $\mathrm{H}_{2} \mathrm{O}_{2}$ anions $\mathrm{s}^{4,7)}$. The presence of free radicals acts upon chromophore molecules, degrading it into smaller soluble molecules and as consequence of this degradation, there is a reduction in chroma concentration and chromatogens from the tooth ${ }^{18,20)}$.

Since variances such as enamel thickness, extent of bleaching agent penetration and initial tooth color can interfere in results, hematoporphyrin or $\beta$-carotene substituting in vitro tooth models, were used in one study ${ }^{19}$. Similarly, in this study, sample solutions were used with no teeth; so proper evaluations could be realized with minimal variation and better reproducibility. To identify the bleaching effects, methylene blue decomposition was determined through the absorbance of the experimental solutions, as described in previous studies ${ }^{18,21,22)}$. In experimental solutions containing only $\mathrm{TiO}_{2}$, there were minimal changes in bleaching results. In other hand, association between $\mathrm{H}_{2} \mathrm{O}_{2}$ and $\mathrm{TiO}_{2}$ showed $\mathrm{MB}$ decreased even without light irradiation. According to some researchers ${ }^{18)}$, during this association it was likely that either $\mathrm{H}_{2} \mathrm{O}_{2}$ or $\mathrm{TiO}_{2}$ produced less free radicals than a combination of both the components. Additionally, 
when these components were light activated, MB concentration greatly decreased (Table 2). Between the two different concentrations of $\mathrm{H}_{2} \mathrm{O}_{2}, 35 \%$ resulted in the most significant reduction in $\mathrm{MB}$, yet, despite the lower $\mathrm{H}_{2} \mathrm{O}_{2}$ concentration for the other experimental group, the bleaching performance of $3.5 \%$ with $\mathrm{TiO}_{2}$ addition was comparable with the higher concentration of $\mathrm{H}_{2} \mathrm{O}_{2}$.

Lower concentrations of $\mathrm{H}_{2} \mathrm{O}_{2} \quad(3.5 \%)$ and light activation showed no significant difference when compared to the same group without light exposure, otherwise, higher peroxide concentrations revealed that when the solution was light irradiated a significant difference was found (SolMB $+\mathrm{H}_{2} \mathrm{O}_{2}$ and SolMB $+\mathrm{H}_{2} \mathrm{O}_{2}+$ Light Irradiation). As a consequence of light activation, a release of hydroxyl-radicals from higher concentrations of $\mathrm{H}_{2} \mathrm{O}_{2}$ may be possible through direct excitation by light (photolysis), which induces the molecular vibration and peroxide degradation ${ }^{9,20)}$. As an effect of peroxide degradation, a rise in temperature might cause damage to adjacent soft tissues and pulp ${ }^{9,18)}$, the temperature increase of $5.5^{\circ} \mathrm{C}$ or higher is considered as a critical value, which should not be exceeded to avoid irreversible pulp damage ${ }^{23,24)}$. To date, the majority of the studies focused on testing the effects of various light sources on bleaching action ${ }^{18-20)}$. This study utilized only the LED-curing unit (440 to $480 \mathrm{~nm}$ ) to analyze $\mathrm{TiO}_{2}$ absorption in the visible light region. Although the increase in temperature was not measured, previous studies relate that the heating of materials irradiated by LED is expected to be minimal, inducing less thermal injury when compared to halogen or plasma arc units ${ }^{25-27)}$.

To obtain a VLA photocatalysis, most times the $\mathrm{TiO}_{2}$ require chemical modifications, such as the addition of metals to its composition. However, controlling the $\mathrm{TiO}_{2}$ morphology has demonstrated to enhance its overall efficiencies ${ }^{28)}$. The mixing of a more active phase (anatase) with a comparatively inactive phase (rutile) could produce a synergistic effect in enhancing the photocatalytic activity ${ }^{29,30)}$. The rutile phase also gives the $\mathrm{P} 25 \mathrm{TiO}_{2}$ an enhanced mesoporosity. The intimate contact between two polymorphs might be sufficient to improve the separation of photogenerated electrons and holes, resulting in the high photocatalytic activity of $\mathrm{TiO}_{2}{ }^{31)}$. The conduction band potential of rutile is more positive than that of anatase $(3.0 \mathrm{eV})$ which means that the rutile phase may act as an electron sink for photogenerated electrons from the conduction band of the anatase phase, as the catalytic activity may be a combined effect of the pore size, the pore size distribution and the appropriate crystal plane on which adsorption takes place $^{28)}$. Regarding the limitations of the experiment, the results for the solutions that comprised both $\mathrm{H}_{2} \mathrm{O}_{2}$ and a $\mathrm{TiO}_{2}$ photocatalyst could be more efficacious for tooth whitening than either one alone.

In this study, the behavior of $\mathrm{TiO}_{2}$ added to bleaching gel products currently marketed was demonstrated in bovine tooth model. Low $\mathrm{H}_{2} \mathrm{O}_{2}$ concentrations gels catalyzed by $\mathrm{TiO}_{2}$ have been extensively studied due to concerns of cellular damage to pulp cells, hypersensitivity ${ }^{3)}$ and the caustic nature of the typical higher concentrations of $\mathrm{H}_{2} \mathrm{O}_{2}$ bleaching gel $\left(\mathrm{H}_{2} \mathrm{O}_{2} 35 \%\right)^{23)}$. Different gel concentrations and contact time were tested in this study, it was evaluated if lower concentrations are suitable for acceptable bleaching results and if shorter periods are as effective as the ones recommended by the manufacturers. The decision to analyze two different bleaching duration (15 and $45 \mathrm{~min}$ ) was determined by a pilot study (data not shown), which tested the bleaching application in 3 different periods: 5, 10 and $15 \mathrm{~min}$. Only for the group with $15 \mathrm{~min}$ of bleaching gel action there was an acceptable change of color in $\Delta E$ units. Thus, the periods analyzed were: 45 min regarding the manufacturer instructions, and $15 \mathrm{~min}$ as experimental subject. Moreover, to simulate tooth discoloration observed clinically, researches have increased the levels of intrinsic tooth color by pre-staining with black tea, coffee, blood or other components ${ }^{18-20,32)}$. In this study, a coffee solution was used to increase the intrinsic tooth color of the bovine teeth.

The concentration of $\mathrm{H}_{2} \mathrm{O}_{2}$ and contact time are the major factors that determine tooth-bleaching efficacy, and higher $\mathrm{H}_{2} \mathrm{O}_{2}$ concentration is associated with better results $^{23)}$. The literature suggests that low concentration of bleaching agent with a longer contact time (home bleaching) is as effective as the in-office bleaching (with a higher concentrated bleaching agent in a shorter period $)^{4)}$. In this study, when $\mathrm{H}_{2} \mathrm{O}_{2}$ concentration and time contact were reduced $\left(\mathrm{H}_{2} \mathrm{O}_{2} 6 \%+\mathrm{TiO}_{2}\right)$ a significant difference with control group $\left(\mathrm{H}_{2} \mathrm{O}_{2} 35 \%\right)$ was found, showing the reduction of the two factors combined influenced tooth bleaching negatively.

In experimental gels containing both $\mathrm{H}_{2} \mathrm{O}_{2}$ and $\mathrm{TiO}_{2}$, there was no significant difference found in the bleaching outcome, regardless the $\mathrm{H}_{2} \mathrm{O}_{2}$ concentration. Moreover, the bleaching agents had differences in application time between experimental and control groups, the experimental group containing $\mathrm{TiO}_{2}$ at $35 \%$ $\mathrm{H}_{2} \mathrm{O}_{2}$ concentration showed no significant difference in $\Delta E$ values compare to control group (45 min), thereby, demonstrating that $\mathrm{TiO}_{2}$ photocatalyst containing gel can accelerate the bleaching process in $30 \mathrm{~min}$. This result shows that the addition of $\mathrm{TiO}_{2}$ may be an alternative to reduce the clinical time required and lowering the possible adverse effects and dentin sensitivity of longer contact time on tooth surface ${ }^{20)}$. Color readout was performed by spectrophotometry following the CIE $L^{*} a^{*} b^{*}$ system, and 3.3 or higher values of $\Delta E$ were considered as an acceptable change of color, according to previous studies ${ }^{20,33,34)}$. The results of the bleaching effectiveness showed that after three applications all groups presented higher $\Delta E$ values than 3.3 , indicating a clinical change of color in all groups. Bleaching was defined as a change in $\Delta E$ units that can be related to an increase in luminosity. Previous clinical studies have often used $\Delta L$ to assess changes in the lightness of a tooth $^{20,23,34,35)}$, corroborating with the $\Delta E$ values found in this study, the $\Delta L$ values gradually increased in all groups.

During the bleaching protocol, two applications were enough to produce a bleaching effect in $\mathrm{H}_{2} \mathrm{O}_{2}$ 
$35 \%$ group and the third application did not show any significance to the final result, as it is shown in some other reports ${ }^{23}$. The $\mathrm{H}_{2} \mathrm{O}_{2} 6 \%+\mathrm{TiO}_{2}$ group also showed no significant difference between second and third sessions. Differently, third gel application demonstrated to be an important factor for higher $\mathrm{H}_{2} \mathrm{O}_{2}$ concentration and reduction in time application $\left(\mathrm{H}_{2} \mathrm{O}_{2} 35 \%+\mathrm{TiO}_{2}\right)$. The bleaching outcome of this group was only possible to be established after the third gel application. In compliance with these findings, it is possible that bleaching protocol should also consider the number of gel applications as a determining factor of the efficacy in $\mathrm{TiO}_{2}$ addition.

For some authors, $\mathrm{H}_{2} \mathrm{O}_{2}$ concentration at $15 \%$ is still too high to be considered as a non-irritant material ${ }^{3}$, evidencing the need for in-office bleaching with lower concentrations of $\mathrm{H}_{2} \mathrm{O}_{2}$. This study demonstrated that $\mathrm{H}_{2} \mathrm{O}_{2} 6 \%+\mathrm{TiO}_{2}$ group showed a clinical change of teeth color after three applications, which can probably meet the needs of seeking faster bleaching treatment and results regarding dentin sensitivity as a nonirritant material. To corroborate, one study tested the effectiveness of $6 \% \mathrm{H}_{2} \mathrm{O}_{2}$ concentration associated with $\mathrm{TiO}_{2}{ }^{23)}$. In one side of the hemiarcade they have utilized $35 \% \mathrm{H}_{2} \mathrm{O}_{2}$ and on the other $6 \% \mathrm{H}_{2} \mathrm{O}_{2}$ with nitrogen-doped $\mathrm{TiO}_{2}$. Results showed both treatments had a change between baseline color, hence that at this design, $6 \%$ $\mathrm{H}_{2} \mathrm{O}_{2}$ is effective for tooth bleaching, reaching good clinical results with less adverse effects. However, this data differs from some reports, which in-office bleaching was tested with $6 \% \mathrm{H}_{2} \mathrm{O}_{2} / \mathrm{TiO} \_\mathrm{N}$ vs. $35 \% \mathrm{H}_{2} \mathrm{O}_{2}{ }^{35)}$. Only for $35 \% \mathrm{H}_{2} \mathrm{O}_{2}$ group the $\Delta E$ values were significantly higher after second bleaching session. This fact can be explained due the consideration of $35 \% \mathrm{H}_{2} \mathrm{O}_{2}$ as control group and its bleaching protocol recommended by the manufacturer was used in all groups, which unfortunately reduced the contact time of $6 \% \mathrm{H}_{2} \mathrm{O}_{2}$ for half of the recommended time, lowering significantly the efficacy of in-office bleaching at this concentration.

According to overall results of this study, all groups showed a change from baseline color. Experimental groups containing $\mathrm{TiO}_{2}$ showed the possibility to reduce the clinical time required in $30 \mathrm{~min}$ without compromising the bleaching outcome. The opportunity to reduce by $30 \mathrm{~min}$ the clinical time could have great impact on patient's satisfaction, since faster appointments to the dentist office are desired. For the clinician, the impact of reducing time for a procedure can result on more patients' appointments per hour, optimizing the time and possibly lowering the side effects, like in less tooth sensitivity to patients. Further investigations, such as randomized clinical trials, are required to confirm the effectiveness stated for the $\mathrm{TiO}_{2}$ and $\mathrm{H}_{2} \mathrm{O}_{2}$ combinations.

\section{CONCLUSIONS}

The null hypothesis was rejected; it was concluded that $\mathrm{TiO}_{2}$ addition was able to actuate on the $\mathrm{H}_{2} \mathrm{O}_{2}$ bleaching gel performance, regardless the concentration of the gel. The photocatalytic activity demonstrated by $\mathrm{TiO}_{2}$ on this study indicates a promisor alternative to reduce by 30 min the contact time of the bleaching gel on the enamel surface.

\section{REFERENCES}

1) Meireles SS, Goettems ML, Dantas RV, Bona AD, Santos IS, Demarco FF. Changes in oral health related quality of life after dental bleaching in a double-blind randomized clinical trial. J Dent 2014; 42: 114-121.

2) Tin-Oo MM, Saddki N, Hassan N. Factors influencing patient satisfaction with dental appearance and treatments they desire to improve aesthetics. BMC Oral Health 2011; 11: 6.

3) Martin J, Fernandez E, Bahamondes V, Werner A, Elphick K, Oliveira OB Jr, Moncada G. Dentin hypersensitivity after teeth bleaching with in-office systems. Randomized clinical trial. Am J Dent 2013; 26: 10-14.

4) Joiner A. The bleaching of teeth: a review of the literature. J Dent 2006; 34: 412-419.

5) Sulieman M, Addy M, MacDonald E, Rees JS. The effect of hydrogen peroxide concentration on the outcome of tooth whitening: an in vitro study. J Dent 2004; 32: 295-299.

6) Luque-Martinez I, Reis A, Schroeder M, Munoz MA, Loguercio $\mathrm{AD}$, Masterson D, Maia LC. Comparison of efficacy of traydelivered carbamide and hydrogen peroxide for at-home bleaching: a systematic review and meta-analysis. Clin Oral Investig 2016; 20: 1419-1433.

7) Sulieman MA. An overview of tooth-bleaching techniques: chemistry, safety and efficacy. Periodontol 2000 2008; 48: 148-169.

8) Marson FC, Sensi LG, Vieira LC, Araujo E. Clinical evaluation of in-office dental bleaching treatments with and without the use of light-activation sources. Oper Dent 2008; 33: 15-22.

9) Buchalla W, Attin T. External bleaching therapy with activation by heat, light or laser-a systematic review. Dent Mater 2007; 23: 586-596.

10) Klaric E, Rakic M, Sever I, Tarle Z. Temperature rise during experimental light-activated bleaching. Lasers Med Sci 2015; 30: $567-576$.

11) Bernardon JK, Sartori N, Ballarin A, Perdigao J, Lopes GC, Baratieri LN. Clinical performance of vital bleaching techniques. Oper Dent 2010; 35: 3-10.

12) Alomari Q, El Daraa E. A randomized clinical trial of in-office dental bleaching with or without light activation. J Contemp Dent Pract 2010; 11: E017-24.

13) Kugel G, Papathanasiou A, Williams AJ 3rd, Anderson C, Ferreira S. Clinical evaluation of chemical and light-activated tooth whitening systems. Compend Contin Educ Dent 2006; 27: 54-62.

14) Fujishima A, Honda K. Electrochemical photolysis of water at a semiconductor electrode. Nature 1972; 238: 37-38.

15) Spasiano D, Marotta R, Malato S, Fernandez-Ibañez P, Di Somma I. Solar photocatalysis: Materials, reactors, some commercial, and pre-industrialized applications. A comprehensive approach. Appl Catal B: Environmental 2015; 170-171: 90-123.

16) Kazuhito H, Hiroshi I, Akira F. $\mathrm{TiO}_{2}$ Photocatalysis: A historical overview and future prospects. Jpn J Appl Phys 2005; 44: 8269.

17) Fujishima A, Rao TN, Tryk DA. Titanium dioxide photocatalysis. J Photochem Photobiol C Photochem Rev 2000; 1: 1-21.

18) Suyama Y, Otsuki M, Ogisu S, Kishikawa R, Tagami J, Ikeda M, Kurata H, Cho T. Effects of light sources and visible lightactivated titanium dioxide photocatalyst on bleaching. Dent Mater J 2009; 28: 693-699.

19) Suemori T, Kato J, Nakazawa T, Akashi G, Igarashi A, Hirai Y, Kumagai Y, Kurata H. Effects of light irradiation on bleaching by a $3.5 \%$ hydrogen peroxide solution containing titanium dioxide. Laser Phys Lett 2008; 5: 379-383. 
20) Kishi A, Otsuki M, Sadr A, Ikeda M, Tagami J. Effect of light units on tooth bleaching with visible-light activating titanium dioxide photocatalyst. Dent Mater J 2011; 30: 723-729.

21) Suemori T, Kato J, Nakazawa T, Akashi G, Hirai Y. A new non-vital tooth bleaching method using titanium dioxide and $3.5 \%$ hydrogen peroxide with a 405 -nm diode laser or a halogen lamp. Laser Phys Lett 2008; 5: 454-459.

22) Tatsuma T, Tachibana S-i, Miwa T, Tryk DA, Fujishima A. Remote bleaching of methylene blue by UV-irradiated $\mathrm{TiO}_{2}$ in the gas phase. J Phys Chem B 1999; 103: 8033-8035.

23) Martin J, Vildosola P, Bersezio C, Herrera A, Bortolatto J, Saad JR, Oliveira OB Jr, Fernández E. Effectiveness of 6\% hydrogen peroxide concentration for tooth bleaching-A double-blind, randomized clinical trial. J Dent 2015; 43: 965972.

24) Tano E, Otsuki M, Kato J, Sadr A, Ikeda M, Tagami J. Effects of $405 \mathrm{~nm}$ diode laser on titanium oxide bleaching activation. Photomed Laser Surg 2012; 30: 648-654.

25) Sulieman M, Addy M, Rees JS. Surface and intra-pulpal temperature rises during tooth bleaching: an in vitro study. Br Dent J 2005; 199: 37-40; discussion 32.

26) Michida SM, Passos SP, Marimoto AR, Garakis MC, de Araujo MA. Intrapulpal temperature variation during bleaching with various activation mechanisms. J Appl Oral Sci 2009; 17: 436-439.

27) Mondelli RF, Soares AF, Pangrazio EG, Wang L, Ishikiriama SK, Bombonatti JF. Evaluation of temperature increase during in-office bleaching. J Appl Oral Sci 2016; 24: 136-141.

28) Pelaez M, Nolan NT, Pillai SC, Seery MK, Falaras P, Kontos
AG, Dunlope PSM, Hamiltone JWJ, Byrne JA, O'Shea K, Entezari MH, Dionysiou DD. A review on the visible light active titanium dioxide photocatalysts for environmental applications. Appl Catal B 2012; 125: 331-349.

29) Linsebigler $\mathrm{AL}, \mathrm{Lu} \mathrm{G}$, Yates JT. Photocatalysis on TiO surfaces: principles, mechanisms, andselected results. Chem Rev 1995; 95: 735-758.

30) Hurum DC, Gray KA, Rajh T, Thurnauer MC. Recombination pathways in the Degussa P25 formulation of $\mathrm{TiO}_{2}$ : surface versus lattice mechanisms. J Phys Chem 2005; 109: 977-980.

31) Datye AK, Riegel G, Bolton JR, Huang M, Prairie MR. Microstructural characterization of a fumed titanium dioxide photocatalyst. J Solid State Chem 1995; 115: 236-239.

32) Pirolo R, Mondelli RF, Correr GM, Gonzaga CC, Furuse AY. Effect of coffee and a cola-based soft drink on the color stability of bleached bovine incisors considering the time elapsed after bleaching. J Appl Oral Sci 2014; 22: 534-540.

33) Lindsey DT, Wee AG. Perceptibility and acceptability of CIELAB color differences in computer-simulated teeth. J Dent 2007; 35: 593-599.

34) Ruyter IE, Nilner K, Moller B. Color stability of dental composite resin materials for crown and bridge veneers. Dent Mater 1987; 3: 246-251.

35) Bortolatto JF, Trevisan TC, Bernardi PS, Fernandez E, Dovigo LN, Loguercio AD, Batista de Oliveira Jr O, Pretel H. A novel approach for in-office tooth bleaching with $6 \% \mathrm{H}_{2} \mathrm{O}_{2} /$ TiO_N and LED/laser system-a controlled, triple-blinded, randomized clinical trial. Lasers Med Sci 2016; 31: 437-444. 